\title{
IJBF INFLUENCE OF TRANSACTION COSTS ON FOREIGN EXCHANGE OPTION CONTRACTS: INTRA-DAILY TESTS
}

\author{
Ariful Hoque, Meher Manzur, and Geoffrey Poitras \\ University of Southern Queensland, Curtin Business \\ School, and Simon Fraser University
}

\begin{abstract}
This paper tests the impact of transaction cost specification on deviations from lower boundary and put-call parity properties. Using PHLX traded foreign exchange options, prices for puts and calls are matched to the nearest five minutes. The results indicate how boundaries on the arbitrage profit function determined by alternative measures of transactions costs can impact the interpretation of deviations from distribution free properties of options such as put-call parity.
\end{abstract}

Keywords: Put-call parity; Market efficiency; Arbitrage; European options JEL classification: G13, G15, F31

\section{Introduction}

This paper examines the impact of transaction costs on the distribution-free properties of European foreign exchange options traded on the Philadelphia Exchange (PHLX) from Aug. 2005-July 2006. Empirical tests were conducted using intra-daily option quotes observed at five minutes intervals. Deviations from put-call parity (PCP) were examined to determine the role of alternative transaction cost measures. A more formal statistical procedure was also employed to test the factors determining deviations from PCP. The results extended previous studies that examined the impact of transaction costs on PCP deviations for stock index options, e.g., Vipul (2008), Garray, Ordonez and Gonzalez (2003) and Wagner, Ellis and Dubofsky (1996), and Hoque, Chan and Manzur (2008) for foreign currency options. The paper is organized as follows. In Section 2, transaction cost measures are specified and discussed. Section 3 gives an overview of the distribution free properties of option prices being considered: a lower boundary condition; and, put-call parity. Section 4 describes the data used in this study. Section 5 provides empirical 
results for deviations from distribution free conditions. Section 6 contains a review of a more formal econometric analysis. The final section presents conclusions of the paper.

\section{Transaction Cost Measures}

At least since Gould and Galai (1974), the role of transaction costs in determining deviations from the PCP relationship have been of interest. In foreign exchange options markets, these costs are of various types: bid-ask spreads commissions; and, other types of costs such as clearing fees, exchange fees, and exercise fees. The actual impact of different types of transaction costs are market and trader specific and costs associated with the marginal trader are difficult to determine due to the lack of precise data about specific trades. Studies going back to Demsetz (1968), Phillips and Smith (1980) and Stoll (1989), identified the bidask spread as the most important implicit transaction cost. However, in assessing deviations from put-call parity, it is not apparent when a trade is initiated to exploit an observed deviation whether the trade will be closed out prior to the expiration date. Holding the trade to expiration and delivering on the underlying positions involve different transaction costs than a trade closed out prior to that date which requires additional transactions costs, especially bid-ask spreads, to be assessed.

To study the impact of different transaction cost measures associated with put-call parity deviations, the following different categories of transaction costs are considered: (A) minimum transactions costs, where only the bid-ask spreads on the initial trade are considered; (B) costs in (A) plus additional estimated bid-ask spreads associated with closing out the call, put and exchange rate positions prior to expiration; and, (C) maximum transactions costs, including bid-ask spreads from (A) and (B) plus 'other transaction costs' that includes commissions and other fixed costs. Recognizing that 'other transaction costs' are more difficult to estimate, the identifiable costs for a one-lot, PHLX options contract are taken as:

\begin{tabular}{|ll|}
\hline Options Commission & $\begin{array}{l}\$ 1.75 \text { per contract (minimum per } \\
\text { order) }\end{array}$ \\
$\begin{array}{l}\text { PHLX FOREX Options Exchange fees } \\
\text { Option clearing corporation }(\mathrm{OCC}) \text { fees: }\end{array}$ & \\
Clearing fees & $\$ 0.05$ per contract \\
Exercise fees & $\$ 1.00$ per contract (per line item) \\
Clearing member authorization stamp & $\$ 23.00$ per stamp (minimum 1 \\
& contract) \\
Total & $\$ 26.24$ per contract \\
\hline
\end{tabular}

In turn, because 'maximum transaction costs' reflect costs associated onelot trading, this measure can be considered as the upper bound for transaction costs associated with put-call parity deviations. 


\section{Two Distribution Free Properties}

In this section, two distribution-free properties of currency option prices are examined: a lower boundary condition (LBC); and, put-call parity (PCP). Assessing the role of transactions costs requires the trading strategies associated with these relationships to be specified using appropriate bid and ask rates. Active execution requires that purchases (borrowing) be made at the ask and sales (lending) be made at the bid.

\section{Lower Boundary Condition}

The lower boundary condition used in this study is obtained from the standard lower boundary condition for a European currency option. In the case of a call, this condition can be stated, e.g.,

Poitras (2002, p.378):

$$
C_{t}[S, X, T] \geq \max \left[0, S_{t} B\left[R_{T}^{*}\right]-X B\left[R_{T}\right]\right]
$$

where: $C_{t}[S, X, T] \equiv C_{t}=$ call option price in domestic (US) currency at time $\mathrm{t} ; \mathrm{T}=$ time to expiration time of the option measured in fractions of a year; $R_{T}$ and $R_{T}^{*}$ are the time t domestic and foreign currency interest rates with maturity date T; $B\left[R_{T}\right]=\exp \left[-R_{T}\right]$ and $B\left[R_{T}^{*}\right]=\exp \left[-R_{T}^{*}\right]$, are the continuously compounded present value of US\$1 or FX\$1 to be paid at T; S $=$ foreign exchange rate ( $\$ \mathrm{US} / \mathrm{FX} \$$ ) at time $\mathrm{t}$; and, $\mathrm{X}=$ option exercise price in domestic currency. Violation of this condition allows for: $S_{t} B\left[R_{T}^{*}\right]$ units of FX to be borrowed at $R_{T}^{*}$; the funds converted to domestic currency at $\mathrm{S}_{\mathrm{t}}$ to purchase the call at $\mathrm{C}_{t}$, and invest $X B\left[R_{T}\right]$. By assumption that the $\mathrm{LBC}$ is violated, there is an arbitrage profit remaining because the investment will mature to $X$ which will be used to exercise the call for $\mathrm{S}_{T}$ which is used to settle the loan.

The LBC is a relatively weak arbitrage condition compared to PCP. If actual time dated prices used by traders could be continuously observed, it is almost certain that few if any LBC deviations would be found. As such, tests of the LBC condition serve to benchmark sample noise that can arise from a variety of factors such as data error, lack of synchronous observations, variations in accuracy across data providers and so on. The European lower boundary restriction on call and put option prices can empirically be re-expressed as inequalities:

$$
\begin{aligned}
& C_{t}[S, X, T] B\left[R_{T}\right]^{-1} \geq C_{t} \geq S_{t}-X \geq \max \left[0, S_{t}-X\right] \\
& P_{t}[S, X, T] B\left[R_{T}\right]^{-1} \geq P_{t} \geq X-S_{t} \geq \max \left[0, X-S_{t}\right]
\end{aligned}
$$

where: $P_{t}[S, X, T] \equiv P_{t}=$ put option price in domestic currency; and, $B\left[R_{T}\right]^{-1}$ is the future value of $\$ 1$ borrowed at t. To achieve equivalence with the distribution free lower boundary condition for a European currency option, the 
empirical observation that $B\left[R_{T}\right]^{-1} B\left[R_{T}^{*}\right]<1$ is used (see Table 3 ) to get the LBC used in this study:

$$
C_{t}[S, X, T] B\left[R_{T}\right]^{-1} \geq S_{t}-X \quad P_{t}[S, X, T] B\left[R_{T}\right]^{-1} \geq X-S_{t}
$$

Due to $B\left[R_{T}\right]^{-1}$ these conditions are slightly weaker upper bound on option prices than the standard European LBC.

\section{Put-Call Parity}

The PCP arbitrage condition is a distribution free property for put and call options with the same exercise price and expiration date, e.g., Poitras, Veld and Zabolotnyuk (2009). More precisely:

$$
C_{t}[S, X, T]+X B\left[R_{T}\right]=S_{t} B\left[R_{T}^{*}\right]+P_{t}[S, X, T]
$$

The two arbitrage trading strategies associated with PCP depend on whether the call or put is overpriced. When $\mathrm{C}>\mathrm{SB}^{*}+\mathrm{P}-\mathrm{XB}$ then a conversion strategy is executed where the call is sold and $\mathrm{XB}$ is borrowed, with the proceeds used to buy the put and the balance converted at $\mathrm{S}_{t}$ and used to buy the foreign $\mathrm{B}^{*}$. This generates an arbitrage profit by assumption at $\mathrm{T}$. This trade is sometimes referred to as the long PCP strategy. Similarly, the arbitrage when the put option is overpriced, $\mathrm{P}>\mathrm{XB}+\mathrm{C}-\mathrm{SB}^{*}$ is the reversal strategy also known as the short PCP strategy.

\section{Deviation Test Framework}

Bid and ask prices play a critical role in determining the impact of transactions costs on arbitrage trading. In particular, a conversion strategy would involve: borrowing the present value of the exercise price at the domestic offer rate with maturity date T; writing a call at the bid price; buying a put with the same $\mathrm{X}$ and $\mathrm{T}$ at the ask price; exchanging the remaining balance into foreign currency at ask rate (US\$/C\$); and, investing the proceeds into an appropriate fixed income security with maturity date $\mathrm{T}$ at the foreign bid rate. ${ }^{1}$ Given this, using minimum transactions costs (A) absence of arbitrage requires:

${ }^{1}$. Bid and ask rates for foreign exchange depend on the FX quoting method. When the US\$ is the domestic currency, then the exchange rate into FX $\$$ is quoted as $\$$ US/ $/$ FX. For option prices and prices in general, the bid must always be not greater than the ask. However, for foreign exchange transactions, whether the bid rate for selling US and buying FX is greater than the ask rate for buying US and selling FX depends on the quotation method. For example, when $\$ \mathrm{US} / \mathrm{C} \$=.9575$ is the bid, then $\$ \mathrm{US} / \mathrm{C} \$=.9600$ could be the ask; in this case bid > ask. However, selling \$US and buying Canadian takes place at the ask rate because the bid will receive more C\$ per US\$. In effect, the bid (ask) quote based on C\$/US\$ is translated into ask (bid) quotes based on US\$/C\$. 


$$
\pi(T)_{\text {conv }}=C_{t}^{b}+X B\left[R_{T}\right]^{s}-P_{t}^{a}-S_{t}^{a} B\left[R_{T}^{*}\right]^{l} \leq 0
$$

Conversely, a reversal strategy involves: borrowing the present value of one unit foreign currency at ask rate; exchanging these funds from foreign into domestic currency at the bid rate (US\$/C\$); writing a put at the bid price; buying a call with the same $\mathrm{X}$ and $\mathrm{T}$ at ask price; and, investing the balance into an appropriate fixed income security with maturity date $\mathrm{T}$. The absence of arbitrage condition for the reversal strategy is:

$$
\pi(T)_{\text {rev }}=P_{t}^{b}+S_{t}^{b} B\left[R_{T}^{*}\right]^{s}-C_{t}^{a}-X B\left[R_{T}\right]^{l} \leq 0
$$

In both cases, the assumption is that the arbitrage will be held until the expiration and maturity date $(\mathrm{T})$.

In calculating the empirical deviations when other transactions costs are also included, the following arbitrage profit function is used for the conversion strategy:

$$
\pi(T)_{c o n v, i}=C_{t}^{b}+X B\left[R_{T}\right]^{s}-P_{t}^{a}-S_{t}^{a} B\left[R_{T}^{*}\right]^{l}-T C_{i, t} \leq 0
$$

Similarly, for the reversal strategy:

$$
\pi(T)_{r e v, i}=P_{t}^{b}+S_{t}^{b} B\left[R_{T}^{*}\right]^{s}-C_{t}^{a}-X B\left[R_{T}\right]^{l}-T C_{i, t} \leq 0
$$

where $T C$ is fixed transactions costs per trade and $i$ refers to one of two cases (B and C) for calculating such costs. In contrast to minimum transaction costs (A), case B includes bid-ask costs for trades closed out prior to maturity. This is a more complicated task because transactions costs for actual close-out trades cannot be accurately determined, e.g., Bodurtha and Courtadon (1986, 1995). In practice, there is a timing option that permits traders to sell at the ask and buy at the bid for some, but not necessarily all, of the positions involved in the trade. With this in mind, additional bid-ask transaction costs (B) for the conversion and reversal trades are determined as:

$$
T C_{B, t}=\left[C_{t}^{a}-C_{t}^{b}\right]+\left[P_{t}^{a}-P_{t}^{b}\right]+\left[S_{t}^{a}-S_{t}^{b}\right]
$$

For the maximum transaction costs case (C), \$26.24 per contract is added to $T C_{B}$, to obtain $T C_{C}$ where the per contract cost is appropriately adjusted to reflect the notional principal of the contract.

Tests of arbitrage relationships such as PCP depend fundamentally on the quality of the data employed. In particular, any study involving bid and ask option prices has to confront the difficulty of determining, say, the 'ask' price from the available spectrum of market and limit quotes available at a given point in time. Being a less restrictive condition than PCP, tests of the LBC serve to benchmark the data quality used in PCP tests. With this in mind, the following absence of arbitrage LBC conditions can be developed for both puts and calls: 
$\pi_{L B C, \text { call }}=C_{t}^{a} B\left[R_{T}\right]^{l}-\left(S_{t}^{b}-X\right) \leq 0 \quad \pi_{L B C, p u t}=P_{t}^{a} B\left[R_{T}\right]^{l}-\left(X-S_{t}^{a}\right) \leq 0$

For deviations associated with transaction cost measures $\mathrm{B}$ and $\mathrm{C}$, these $\mathrm{LBC}$ conditions are augmented to include $T C L_{B}$ and $T C L_{C}$ (e.g., $\left.\pi_{L B C, \text { call }, B}=\pi_{L B C, \text { call }}+T C L_{B, c, t}\right)$ where:

$$
T C L_{B, c, t}=\left[C_{t}^{a}-C_{t}^{b}\right]+\left[S_{t}^{a}-S_{t}^{b}\right] \quad T C L_{B, p, t}=\left[P_{t}^{a}-P_{t}^{b}\right]+\left[S_{t}^{a}-S_{t}^{b}\right]
$$

In other words, a distinction is made for transactions costs associated with the LBC condition for calls, which uses the bid-ask spread for calls, and conversely for puts. In both cases, the two arbitrage profit functions using $T C L_{C}$ involve addition of $\$ 26.25$ per contract to $T C L_{B, c, t}$ and $T C L_{B, p, t}$.

\section{Data}

This study uses intra-day price quotes for the British pound, Swiss franc and Euro options traded on the Philadelphia Stock Exchange (PHLX). These data are obtained from Reuter's database through SIRCA for the trading period from 1 August 2005 to 31 July 2006. Each intra-day observation contains the options price (bid and ask), strike price, maturity date and trading time indicated with a time-stamp. Put and call data are matched at five minute intervals. For example, put-call pairs traded at 09:05, 09:10, 09:15 and so on are included in the sample. The Structured Query Language (SQL) was used to obtain the synchronised putcall pairs as given in Tables 1 and 2. Due to significant differences in trading volume, the number of pair-wise put-call observations varies for each currency. For the British pound, a 'small sample' of 618 synchronized put-call pairs were obtained from 13,414 and 285,211 observations for calls and puts, respectively. For the Swiss franc, there are 41,212 put-call pairs and a 'large sample' of 197,815 put-call pairs for the Euro. Available option maturities are for 3, 6, 9 , and 12 months. The expiration months are March, June, September and December. If the expiration month has 5 Fridays, the options expire on the third Friday, otherwise it is the second Friday of the expiration month. The option contract size was $£ 10000$, SF10000 and $£ 10000$ for British pound, Swiss franc and Euro, respectively.

Significantly, the daily closing spot FX rate (bid and ask) and daily closing Eurodollar and Eurocurrency interest rates (bid and ask), obtained from DATASTREAM, were employed instead of the corresponding time dated spot FX rate and interest rates. While the prices for put and call pairs were time synchronized, because the FX and interest rates used to determine the PCP 
deviations were not synchronized, the deviations did not necessarily represent actual arbitrage opportunities. However, due to PHLX market organization and trading conventions used to price and trade PHLX foreign exchange options, ${ }^{2}$ the use of synchronized data for rates would produce deviations that are primarily due to noise arising from, say, difficulties in determining actual bid and ask prices at which trades could actually be executed. Descriptive statistics for spot FX rates and interest rates based on daily data are presented in Table 3. For the British pound, the mid-spot FX rate mean, i.e., [(spot bid mean + spot ask mean)/2] was $\$ 1.7857$, slightly higher than the strike price mean reported in Table 2 by $\$ 0.0857$ (= $\$ 1.7857$ - $\$ 1.7000)$. In contrast, the difference between the mid-spot price mean and strike price mean is $\$ 0.0069$ and $\$ 0.0183$ for Swiss franc and Euro, respectively. This indicates that, on average, these put-call option pairs are typically trading at or near the money.

Table 1: Synchronized Put-Call Data*

\begin{tabular}{lcccc}
\hline Options & $\begin{array}{c}\text { Sample } \\
\text { period }\end{array}$ & Option type & NOB & $\begin{array}{c}\text { Synchronized } \\
\text { put-call pairs }\end{array}$ \\
\hline British pound & $01 / 08 / 2005$ & Call & 13,414 & 618 \\
& $31 / 07 / 2006$ & Put & 285,211 & \\
Swiss franc & & Call & 583,230 & \multirow{2}{*}{41,212} \\
& & Put & 897,258 & \\
Euro & Call & $3,397,196$ & \multirow{2}{*}{197,815} \\
& & Put & $3,547,101$ & \\
\hline
\end{tabular}

* The synchronized put-call pairs are obtained as the matching puts and calls data for same trading date and time, maturity date and strike price at an interval of 5 minutes during trading hours.

2. The PHLX demutualized in 2003 and, circa Sept. 2005, was owned by 505 shareholders. Investment banks and brokerage firms collectively owned 45 percent of the PHLX, with an option to purchase additional ownership. Merrill Lynch, Citadel Derivatives Group and Morgan Stanley, each paid \$7.5 million for 10 percent of the PHLX. Citigroup, Credit Suisse First Boston and UBS each paid S3.75 million for 5\% (Scotti, 2005). Each partner had the option to double its ownership if it delivered a certain level of order flow to the exchange. The amount of order flow sent to the PHLX determined the cost to exercise its option to double ownership. During the sample period examined in this study, high foreign currency option volume was generated by the trade through protection provided by Reg NMS that dictated when the best quoted price in the National Market System was from PHLX, that quote would have priority over all others in the NMS. The PHLX was purchased by the NASDAQ group in 2008. 
Table 2: Descriptive Statistics: Call, Put and Strike Prices, Intra-Daily Data*

\begin{tabular}{|c|c|c|c|c|c|c|}
\hline \multirow{2}{*}{ Currency } & \multirow{2}{*}{$\begin{array}{c}\text { Statistical } \\
\text { measures }\end{array}$} & \multicolumn{2}{|c|}{ Call } & \multicolumn{2}{|c|}{ Put } & \multirow{2}{*}{$\begin{array}{l}\text { Strike } \\
\text { price }\end{array}$} \\
\hline & & Bid & Ask & Bid & Ask & \\
\hline \multirow[t]{5}{*}{ British pound } & Mean & 5.67 & 5.93 & 4.17 & 4.42 & 170 \\
\hline & Median & 5.71 & 5.96 & 4.15 & 4.40 & 170 \\
\hline & Skewness & 0.12 & 0.12 & -0.02 & -0.02 & NA \\
\hline & Kurtosis & 3.27 & 3.27 & 2.48 & 2.48 & NA \\
\hline & JB & 3.36 & 3.36 & $6.94 *$ & $6.94 *$ & NA \\
\hline \multirow[t]{5}{*}{ Swiss franc } & Mean & 1.58 & 1.62 & 1.44 & 1.51 & 77.83 \\
\hline & Median & 1.38 & 1.44 & 1.27 & 1.3 & 78.00 \\
\hline & Skewness & 0.40 & 0.40 & 0.40 & 0.39 & -0.41 \\
\hline & Kurtosis & 2.06 & 2.05 & 2.07 & 2.06 & 2.12 \\
\hline & JB & $2.64 \mathrm{E} 3 *$ & $2.63 \mathrm{E} 3 *$ & $2.57 \mathrm{E} 3 *$ & $2.56 \mathrm{E} 3 *$ & $2.43 \mathrm{E} 3 *$ \\
\hline \multirow[t]{5}{*}{ Euro } & Mean & 2.58 & 2.71 & 2.57 & 2.70 & 124.06 \\
\hline & Median & 2.51 & 2.66 & 2.47 & 2.62 & 123 \\
\hline & Skewness & 0.42 & 0.38 & 0.40 & 0.37 & 0.34 \\
\hline & Kurtosis & 3.22 & 3.14 & 2.76 & 2.72 & 2.35 \\
\hline & JB & $6.23 \mathrm{E} 3 *$ & $5.03 \mathrm{E} 3 *$ & $5.82 \mathrm{E} 3 *$ & $5.16 \mathrm{E} 3 *$ & $7.23 \mathrm{E} 3 *$ \\
\hline
\end{tabular}

* The Jarque-Bera (JB) statistic follows a chi-square distribution with 2 degree of freedom. The critical value of the chi-square distribution is 5.99 at the $5 \%$ level of significance. The statistical significance level at $5 \%$ is denoted by *. NA denotes not applicable.

Table 3: Descriptive Statistics: Spot Exchange and Interest Rates, Daily Data*

\begin{tabular}{|c|c|c|c|c|c|}
\hline \multirow{2}{*}{ Currency } & \multirow{2}{*}{$\begin{array}{l}\text { Statistical } \\
\text { measures }\end{array}$} & \multicolumn{2}{|c|}{$\begin{array}{l}\text { Spot foreign } \\
\text { exchange rate }\end{array}$} & \multicolumn{2}{|c|}{$\begin{array}{l}\text { Interest } \\
\text { rate }\end{array}$} \\
\hline & & Bid & Ask & Bid & Ask \\
\hline \multirow[t]{5}{*}{ British pound } & Mean & 1.7857 & 1.7861 & 4.6426 & 4.6915 \\
\hline & Median & 1.7729 & 1.7733 & 4.6000 & 4.6500 \\
\hline & Skewness & 0.5269 & 0.5268 & 0.5307 & 0.5315 \\
\hline & Kurtosis & 2.0847 & 2.0842 & 1.9986 & 2.0115 \\
\hline & JB & $21.1857^{*}$ & $21.1930^{*}$ & $23.1567 *$ & $22.9141 *$ \\
\hline \multirow[t]{5}{*}{ Swiss franc } & Mean & 0.7849 & 0.7854 & 1.4276 & 1.4751 \\
\hline & Median & 0.7812 & 0.7816 & 1.3900 & 1.4400 \\
\hline & Skewness & 0.4695 & 0.4689 & -0.2977 & -0.3025 \\
\hline & Kurtosis & 2.0359 & 2.0357 & 1.9851 & 1.9835 \\
\hline & JB & $19.6959 *$ & $19.6775^{*}$ & $15.0576^{*}$ & $15.2158 *$ \\
\hline
\end{tabular}


Table 3: Descriptive Statistics: Spot Exchange and Interest Rates, Daily Data*

\begin{tabular}{|c|c|c|c|c|c|}
\hline \multirow{2}{*}{ Currency } & \multirow{2}{*}{$\begin{array}{c}\text { Statistical } \\
\text { measures }\end{array}$} & \multicolumn{2}{|c|}{$\begin{array}{l}\text { Spot foreign } \\
\text { exchange rate }\end{array}$} & \multicolumn{2}{|c|}{$\begin{array}{l}\text { Interest } \\
\text { rate }\end{array}$} \\
\hline & & Bid & Ask & Bid & Ask \\
\hline \multirow[t]{5}{*}{ Euro } & Mean & 1.2222 & 1.2225 & 2.8462 & 2.8763 \\
\hline & Median & 1.2132 & 1.2135 & 2.8600 & 2.8900 \\
\hline & Skewness & 0.4119 & 0.4118 & -0.1912 & -0.1916 \\
\hline & Kurtosis & 2.0136 & 2.0136 & 1.8516 & 1.8519 \\
\hline & JB & $17.9602 *$ & $17.9580 *$ & $15.9329 *$ & $15.9331 *$ \\
\hline \multirow[t]{5}{*}{ U.S. dollar } & Mean & & & 4.9169 & 4.9469 \\
\hline & Median & & & 4.8800 & 4.9100 \\
\hline & Skewness & & & -0.1792 & -0.1792 \\
\hline & Kurtosis & & & 2.0718 & 2.0718 \\
\hline & JB & & & $10.7666^{*}$ & $10.7666^{*}$ \\
\hline
\end{tabular}

* See Notes to Table 2

\section{Empirical Results for Deviations}

This section presents empirical results for LBC and PCP deviations for different categories of transaction costs. The number of LBC deviations is reported in Table 4 and summarized in Table 5. The mean profit (\$) per contract for individual currencies is calculated as the average of the arbitrage profit (\$) for each LBC deviation, multiplied by the contract size. Similarly, mean profit (\$) for all currencies is calculated as summation of total arbitrage profit (\$) for each currency (British pound, Swiss franc and Euro) divided by total number of PCP deviations for all currencies.

As can be seen in the minimum transactions cost case (Panel A), the LBC deviations for British pound, Swiss franc and Euro, respectively, are: for call options are $0,0.45$ percent, and 0.53 percent and, for all currencies jointly, $0.52 \%$; for put options, LBC deviations represent $0,2.56$, and 2.69 per cent and, for all currencies taken together, 2.64\%. Consistent with Shastri and Tandon (1985), the results for all currencies jointly indicate that LBC deviations in put prices are higher than those for call prices. For all currencies taken together, the average profit for both call and put options is about \$US25 (or about 1.5 percent) per contract due to the deviation from the LBC for calls and puts. Comparing these results with round-trip bid-ask spreads (B) and total transactions costs (C), the number and percentage of LBC deviations is progressively reduced with the ratio of $\%$ put deviations to $\%$ call deviations staying relative constant at approximately five times more put deviations than for calls. 
Table 4: LBC Tests for Call and Put Option Price*

\begin{tabular}{|c|c|c|c|c|c|c|}
\hline \multirow[t]{3}{*}{ Options on } & \multicolumn{6}{|c|}{ LBC violation and arbitrage profit $(\$)$ per contract } \\
\hline & \multicolumn{3}{|c|}{ Call option price } & \multicolumn{3}{|c|}{ Put option price } \\
\hline & $\begin{array}{c}\text { No of } \\
\text { violation }\end{array}$ & $\begin{array}{c}\text { Violation } \\
\%\end{array}$ & $\begin{array}{c}\text { Mean } \\
\text { profit }(\$)\end{array}$ & $\begin{array}{c}\text { No of } \\
\text { violation }\end{array}$ & $\begin{array}{c}\text { Violation } \\
\%\end{array}$ & $\begin{array}{c}\text { Mean } \\
\text { profit }(\$)\end{array}$ \\
\hline \multicolumn{7}{|c|}{ A: with one-way bid-ask spreads } \\
\hline British pound & 0 & 0 & 0 & 0 & 0 & 0 \\
\hline Swiss franc & 187 & 0.45 & 17.70 & 1053 & 2.56 & 13.46 \\
\hline Euro & 1055 & 0.53 & 25.24 & 5278 & 2.69 & 29.25 \\
\hline All currencies & 1242 & 0.52 & 23.10 & 6331 & 2.64 & 26.62 \\
\hline \multicolumn{7}{|c|}{$\underline{B}$ : with round trip bid-ask spreads } \\
\hline British pound & 0 & 0 & 0 & 0 & 0 & 0 \\
\hline Swiss franc & 119 & 0.29 & 14.75 & 487 & 1.18 & 13.20 \\
\hline Euro & 633 & 0.32 & 24.42 & 3269 & 1.65 & 26.25 \\
\hline All currencies & 752 & 0.31 & 22.89 & 3756 & 1.57 & 24.56 \\
\hline \multicolumn{7}{|c|}{ C: with total transaction costs } \\
\hline British pound & 0 & 0 & 0 & 0 & 0 & 0 \\
\hline Swiss franc & 19 & 0.05 & 10.43 & 73 & 0.18 & 14.65 \\
\hline Euro & 248 & 0.13 & 20.50 & 1356 & 0.69 & 21.88 \\
\hline All currencies & 267 & 0.11 & 19.78 & 1429 & 0.60 & 21.51 \\
\hline
\end{tabular}

* The sample size across currencies is 618, 41212, 197815 and 239645 for British pound, Swiss franc, Euro and all currencies, respectively.

Table 5: Comparison of LBC Tests Results*

\begin{tabular}{|c|c|c|c|c|c|c|c|}
\hline \multirow{3}{*}{ Options on } & \multirow{3}{*}{$\begin{array}{c}\text { Sample } \\
\text { Size }\end{array}$} & \multicolumn{6}{|c|}{ Percentage of LBC violation } \\
\hline & & \multicolumn{3}{|c|}{ Call option price } & \multicolumn{3}{|c|}{ Put option price } \\
\hline & & Panel A & Panel B & Panel C & Panel A & Panel B & Panel C \\
\hline British pound & 618 & 0 & 0 & 0 & 0 & 0 & 0 \\
\hline Swiss franc & 41212 & 0.45 & 0.29 & 0.05 & 2.56 & 1.18 & 0.18 \\
\hline Euro & 197815 & 0.53 & 0.32 & 0.13 & 2.69 & 1.65 & 0.69 \\
\hline All currencies & 239645 & 0.52 & 0.31 & 0.11 & 2.64 & 1.57 & 0.60 \\
\hline
\end{tabular}

* Panel A, Panel B and Panel C represent the situations of LBC tests in absence of transaction costs, in presence of bid-ask spreads and in presence of total transaction costs. The sample size across currencies is 618, 41212, 197815 and 239645 for British pound, Swiss franc, Euro and all currencies, respectively. 
Examination of deviations from the LBC condition provides an initial check on the quality of the PCP deviations being examined. By introducing moneyness and the relationship between the prices of put call pairs, PCP provides a more demanding arbitrage condition than LBC. Given this, the impact of transactions costs on the number of PCP deviations is reported in Table 6 and summarized in Table 7. Using minimum transaction costs, the percentage of PCP deviations due to overpricing of call is $0.32,39.61$, and 33.97 per cent for British pound, Swiss franc and Euro, respectively. For all currencies jointly, the corresponding number is $34.86 \%$. Due to overpricing of puts, the PCP deviations represent 53.69, 21.40, and 23.75\% for British pound, Swiss franc and Euro, respectively. For all currencies, the corresponding number is $23.43 \%$. Overall, calls tend to be overpriced more frequently than the puts. These results are in agreement with El-Mekkaoui and Flood (1998), Wagner et al. (1996), and Berg et al. (1996). When round-trip bid-ask spreads are used to measure transaction costs (B), the percentage of PCP deviations drops dramatically for all currencies. Using total transaction costs (C), PCP deviations fall almost to the level of LBC violations.

Table 6: PCP Tests for Conversion and Reversal Strategy*

\begin{tabular}{|c|c|c|c|c|c|c|}
\hline \multirow{3}{*}{ Options on } & \multicolumn{6}{|c|}{ PCP Violations and Arbitrage Profit } \\
\hline & \multicolumn{3}{|c|}{ Conversion strategy } & \multicolumn{3}{|c|}{ Reversal strategy } \\
\hline & $\begin{array}{l}\text { No of } \\
\text { violation }\end{array}$ & $\begin{array}{c}\text { Violation } \\
\%\end{array}$ & $\begin{array}{c}\text { Mean } \\
\text { profit (\$) }\end{array}$ & $\begin{array}{c}\text { No of } \\
\text { violation }\end{array}$ & $\begin{array}{c}\text { Violation } \\
\%\end{array}$ & $\begin{array}{c}\text { Mean } \\
\text { profit (\$) }\end{array}$ \\
\hline \multicolumn{7}{|c|}{ A: minimum transaction costs } \\
\hline British pound & 2 & 0.32 & 9.96 & 338 & 53.69 & 41.74 \\
\hline Swiss franc & 16323 & 39.61 & 17.13 & 8820 & 21.40 & 18.78 \\
\hline Euro & 67205 & 33.97 & 28.18 & 46987 & 23.75 & 30.21 \\
\hline All currencies & 83530 & 34.86 & 18.42 & 56145 & 23.43 & 30.24 \\
\hline \multicolumn{7}{|c|}{ B: with round trip bid-ask spreads } \\
\hline British pound & 0 & 0 & 0 & 117 & 18.93 & 36.57 \\
\hline Swiss franc & 6291 & 14.26 & 16.15 & 3587 & 8.70 & 17.53 \\
\hline Euro & 25,632 & 12.96 & 28.24 & 20122 & 10.17 & 24.89 \\
\hline All currencies & 31,923 & 13.32 & 25.85 & 23826 & 12.60 & 23.84 \\
\hline \multicolumn{7}{|c|}{ C: with total transaction costs } \\
\hline British pound & 0 & 0 & 0 & 75 & 12.14 & 22.51 \\
\hline Swiss franc & 1,183 & 2.87 & 12.11 & 871 & 2.11 & 13.76 \\
\hline Euro & 10,785 & 4.45 & 23.95 & 8332 & 4.21 & 20.19 \\
\hline All currencies & 11,968 & 4.99 & 22.78 & 7411 & 3.09 & 24.54 \\
\hline
\end{tabular}

* The sample size is 618, 41212, 197815 and 239645 for British pound, Swiss franc, Euro and all currencies, respectively. The mean profit (\$) is per options contract. 
Table 7: Comparison of PCP Tests Results*

\begin{tabular}{|c|c|c|c|c|c|c|c|}
\hline \multirow{3}{*}{ Options on } & \multirow{3}{*}{$\begin{array}{c}\text { Sample } \\
\text { Size }\end{array}$} & \multicolumn{6}{|c|}{ Percentage of PCP violation } \\
\hline & & \multicolumn{3}{|c|}{ Conversion strategy } & \multicolumn{3}{|c|}{ Reversal strategy } \\
\hline & & Panel A & Panel B & Panel C & Panel A & Panel B & Panel C \\
\hline British pound & 618 & 0.32 & 0 & 0 & 54.69 & 18.93 & 12.14 \\
\hline Swiss franc & 41,212 & 39.61 & 14.26 & 2.87 & 21.40 & 8.70 & 2.11 \\
\hline Euro & 197,815 & 33.97 & 12.96 & 4.45 & 23.75 & 10.17 & 4.21 \\
\hline All currency & 239,645 & 34.86 & 13.32 & 4.99 & 23.43 & 12.60 & 3.09 \\
\hline
\end{tabular}

* Panel A, Panel B and Panel C represent PCP tests situations in absence of transaction costs (A), in presence of bid-ask spreads (B) and in presence of total transaction costs (C), respectively. The sample sizes are 618, 41212, 197815 and 239645 for British pound, Swiss franc, Euro and a currencies, respectively.

\section{Decomposition of Deviations}

To determine whether PCP deviations are systematically related to the moneyness of options, the PCP deviations for minimum transaction costs are decomposed into where the calls and puts are in-the money (ITM), out-of-the-money (OTM) and at-the-money (ATM). The results under conversion strategy are summarized in Table 8 and the reversal strategy in Table 9. In Table 8, the PCP deviations are evaluated in three states. In state 1, calls and puts are ITM and OTM, respectively. In this situation, PCP deviations are created by the difference between call bid price and put ask price being larger than the difference of present value of spot FX ask and strike price. In state 2, calls and puts are ATM at same strike price; the call bid price should be equal to the put ask price. In this case, PCP is violated if call bid price is observed to be larger than put ask price. In state 3 , calls and puts are written OTM and ITM, respectively and PCP deviations arise in three possible circumstances: case (i), where call bid price is observed to be higher than put ask; case (ii) where the call bid price is equal to put ask price; and, in case (iii) where the put ask price and call bid price difference is smaller than the difference of present value of strike and spot price.

Table 8: Decomposition of PCP Violations for Conversion Strategy*

\begin{tabular}{|c|c|c|c|}
\hline \multirow{2}{*}{ Deviation States } & \multicolumn{3}{|c|}{ PCP violation } \\
\hline & $\begin{array}{l}\text { British } \\
\text { pound }\end{array}$ & $\begin{array}{l}\text { Swiss } \\
\text { franc }\end{array}$ & Euro \\
\hline $\begin{array}{l}\text { State 1: When calls and puts are ITM and OTM, } \\
\text { respectively at the same strike price, PCP is violated if } \\
\text { call bid and put ask price difference is larger than the } \\
\text { difference of present value of spot ask and strike price. }\end{array}$ & $\begin{array}{c}2 \\
(0.32 \%)\end{array}$ & $\begin{array}{c}2532 \\
(6.15 \%) \\
{[\varnothing 0.12]}\end{array}$ & $\begin{array}{l}14893 \\
(7.53 \%) \\
{[\varnothing 0.24]}\end{array}$ \\
\hline
\end{tabular}


Table 8: Decomposition of PCP Violations for Conversion Strategy*

\begin{tabular}{lccc}
\hline \multirow{2}{*}{ Deviation States } & \multicolumn{3}{c}{ PCP violation } \\
\cline { 2 - 4 } & $\begin{array}{l}\text { British } \\
\text { pound }\end{array}$ & $\begin{array}{c}\text { Swiss } \\
\text { franc }\end{array}$ & Euro \\
\hline State 2: When calls and puts are ATM at same strike & 0 & 142 & 116 \\
price, PCP is violated if call bid price is larger than put & & $(0.34 \%)$ & $(0.06 \%)$ \\
ask price. & & {$[\varnothing 0.20]$} & {$[\varnothing 0.13]$}
\end{tabular}

State 3: When calls and puts are OTM and ITM, respectively at same strike price with, PCP is violated in the following circumstances:

(i) If call bid price is higher than put ask price.

(ii) If call bid price is equal to the put ask price.

(iii) If put ask and call bid price difference is smaller than the difference of present value of strike and spot price.

Total PCP violations under situation C

Total PCP violations for all situations

Average arbitrage profit

* ITM, ATM, and OTM represent in-the-money, at-the-money, and out-of-the-money, respectively. See Notes to Table 7. The percentage of PCP deviations and amounts of option overpricing (in US cents) are given in the parentheses, and brackets respectively.

The results in Table 8 indicate that PCP deviations in state 1 are 0.32 , 6.15, and 7.53 percent for the British pound, Swiss franc and Euro, respectively. Figures in squared parentheses indicate the call is overpriced on average by 0.12 and 0.24 cents for Swiss franc and Euro. In state 2, PCP deviations for Swiss franc $(0.34 \%)$ and Euro $(0.06 \%)$ tend to be small and no deviation is observed for British pound, not surprising given the small number of observations for this currency. In state 3, deviations are considerably larger for Swiss franc (a total of $33.12 \%$ ) and Euro (a total of $26.38 \%$ ). In the last row, the average arbitrage profit amount $(\$)$ is calculated as the average of the call overpriced amount (\$) for each state multiplied by the contract size (reported in data section). For example, the average arbitrage profit of US\$17 for Swiss options is calculated as: $(\phi 0.12+\phi 0.20+\phi 0.19+\phi 0.17+\phi 0.17) / 100=\$ 0.0085 / 5=\$ 0.0017$ (average) $\mathrm{x}$ 
10,000 (contract size) $=\$ 17.00$. Average profits for Swiss franc and Euro are close to the mean profit $(\$)$ per contract under the conversion strategy reported in Panel A of Table 6.

In state 3, OTM calls have a higher overpricing tendency than the ITM counterparts in state 1. For the Swiss franc, the magnitude of overpricing for OTM calls is in the order of more than five times that for ITM calls. The results for the Euro were similar. In market equilibrium, the overpricing tendency of OTM calls is a reflection of option market speculators wanting to make a leveraged speculation by buying foreign currency options at lower premium cost which creates trading opportunities for option writers to offer higher OTM call ask prices than indicated by PCP. Results for put prices, given in Table 9, provided a different picture: it is ITM puts that have a higher tendency to be overpriced than OTM puts. For Swiss franc options, the percentage of observations with overpricing, i.e. PCP deviations, for ITM puts is almost twice that of OTM puts. The results for Euro are similar. In market equilibrium, the ITM put option overpricing tendency reflects the option purchaser's preference for trading ITM put option to obtain effective downside currency protection. This is consistent with the use of put options for insurance in currency risk management, e. g. Poitras (2002, p. 523). Option writers provide the needed liquidity by quoting higher put ask prices than indicated by PCP. This result is consistent with the well-known volatility smile arising from the impact of moneyness on the variation of implied volatilities.

Table 9: Decomposition of PCP Violations for Reversal Strategy*

\begin{tabular}{|c|c|c|c|}
\hline \multirow{2}{*}{ Deviation States } & \multicolumn{3}{|c|}{ PCP violations } \\
\hline & $\begin{array}{l}\text { British } \\
\text { pound }\end{array}$ & $\begin{array}{l}\text { Swiss } \\
\text { franc }\end{array}$ & Euro \\
\hline $\begin{array}{l}\text { Sate 1: When puts and calls are ITM and OTM, } \\
\text { respectively at the same strike price, PCP is violated } \\
\text { if put bid price and call ask price difference is larger } \\
\text { than the difference of present value of strike and spot } \\
\text { exchange rate. }\end{array}$ & 0 & $\begin{array}{c}5701 \\
(13.83 \%) \\
{[\varnothing 0.16]}\end{array}$ & $\begin{array}{c}29884 \\
(15.11 \%) \\
{[\varnothing 0.28]}\end{array}$ \\
\hline $\begin{array}{l}\text { State } 2 \text { : When puts and calls are ATM at same strike } \\
\text { price, PCP is violated if put bid price is larger than call } \\
\text { ask price. }\end{array}$ & 0 & 0 & $\begin{array}{l}20 \\
(0.10 \%) \\
{[\phi 0.12]}\end{array}$ \\
\hline \multicolumn{4}{|l|}{$\begin{array}{l}\text { State 3: When puts and calls are OTM and ITM, } \\
\text { respectively at same strike price, PCP is violated in the } \\
\text { following circumstances: }\end{array}$} \\
\hline (i) If put bid price is higher than call ask price. & 0 & $\begin{array}{c}206 \\
(0.50 \%) \\
{[\phi 0.44]}\end{array}$ & $\begin{array}{c}622 \\
(0.31 \%) \\
{[\notin 0.69]}\end{array}$ \\
\hline
\end{tabular}


Table 9: Decomposition of PCP Violations for Reversal Strategy*

\begin{tabular}{|c|c|c|c|}
\hline \multirow{2}{*}{ Deviation States } & \multicolumn{3}{|c|}{ PCP violations } \\
\hline & $\begin{array}{l}\text { British } \\
\text { pound }\end{array}$ & $\begin{array}{l}\text { Swiss } \\
\text { franc }\end{array}$ & Euro \\
\hline (ii) If put bid price is equal to the call ask price. & 0 & $\begin{array}{c}13 \\
(0.03 \%) \\
{[\varnothing 0.26]}\end{array}$ & $\begin{array}{c}32 \\
(0.01 \%) \\
{[\varnothing 0.54]}\end{array}$ \\
\hline $\begin{array}{l}\text { (iii) If call ask and put bid price difference is smaller } \\
\text { than the difference of present value of spot and strike } \\
\text { price. }\end{array}$ & $\begin{array}{l}338 \\
(53.69 \%) \\
{[\varnothing 0.42]}\end{array}$ & $\begin{array}{l}2900 \\
(7.04 \%) \\
{[\notin 0.22]}\end{array}$ & $\begin{array}{l}16429 \\
(8.31 \%) \\
{[\phi 0.33]}\end{array}$ \\
\hline Total PCP violations under situation $\mathrm{C}$ & $\begin{array}{c}338 \\
(53.69 \%)\end{array}$ & $\begin{array}{c}3119 \\
(7.57 \%)\end{array}$ & $\begin{array}{c}17083 \\
(8.64 \%)\end{array}$ \\
\hline Total PCP violations for all situations & $\begin{array}{c}338 \\
(53.69 \%)\end{array}$ & $\begin{array}{c}8820 \\
(21.40 \%)\end{array}$ & $\begin{array}{c}46987 \\
(23.75 \%)\end{array}$ \\
\hline Average arbitrage profit & $\$ 42.00$ & $\$ 21.60$ & $\$ 39.20$ \\
\hline
\end{tabular}

* ITM, ATM, and OTM represent in-the-money, at-the-money, and out-of-the-money, respectively. The sample size for British pound, Swiss franc and Euro is 618, 41212 and 197815 , respectively. The PCP deviations and amounts of put overpricing (in US cents) are given in the parentheses, and brackets respectively.

\section{Econometric Analysis}

Following Hoque et al. (2008), a more formal statistical analysis was employed to examine the impact of transaction costs on the validity of PCP. Under the null hypothesis that PCP is valid, regression equations were estimated for the conversion and reversal strategy, respectively. Each equation is estimated using all the sample data, e. g. 197,815 put-call pairs are used to estimate each of two Euro regressions. After conducting stationarity tests using the standard augmented Dickey-Fuller (ADF) and Phillips-Perron (PP) tests to check whether a unit root is present in the data series involved, regressions for the conversion strategy were specified as:

$$
C_{t}^{b}-P_{t}^{a}=\lambda_{0}+\lambda_{1}\left(S_{t}^{a} B\left[R_{T}^{*}\right]^{l}-X B\left[R_{T}\right]^{s}\right)+\eta_{t}
$$

Regressions for the reversal strategy were also estimated using:

$$
P_{t}^{b}-C_{t}^{a}=\theta_{0}+\theta_{1}\left(X B\left[R_{T}\right]^{l}-S_{t}^{b} B\left[R_{T}^{*}\right]^{s}\right)+\eta_{t}
$$

where the equation errors are specified to accommodate serial correlation and GARCH effects. A 
Lagrange multiplier (LM) test was conducted for the presence of $\mathrm{GARCH}(\mathrm{r}, \mathrm{s})$ errors in _ $\mathrm{t}$. Once the presence of GARCH errors was confirmed by the LM test, an appropriate lag order was determined by further diagnostic tests. The regressions for the conversion and reversal strategies were initially estimated using ordinary least squares regression. The regression equations were then re-estimated, incorporating adjustments for serial correlation and GARCH effects.

With appropriate error term adjustments, the estimate of $\lambda_{0}$ is not statistically different than 0 for any currency, while $\lambda_{1}$ is statistically less than 1 being: .980 [.00051] for the Swiss franc; and, .974 [.00029] for the Euro with [coefficient standard errors] adjusted for serial correlation and GARCH effects. As with the conversion strategy results, $\theta_{0}=0$ cannot be rejected at any reasonable significance level. The estimates of $\theta_{1}$ are again statistically less than 1 being: .991 [.00041] for the Swiss franc; and,. 967 [.00034] for the Euro. To interpret these results observe that the independent variable is, more-orless, the moneyness of the options. The zero intercepts indicate that bid prices are systematically higher than warranted by PCP, likely to account for market marker profits. To see this, consider ATM options in the conversion trade. Because the bid price is below the ask for a given option, the use of $C^{b}-P^{a}$ as the dependent variable subtracts the higher ask price from the lower bid price. Because ATM means the independent variable will be more-or-less zero, it is expected that the intercept would be negative in this case; just as a positive intercept would be expected if $C^{a}-P^{b}$ were used as the independent variable.

Interpretation of the regression slopes being slightly less than 1 is more complicated. Given that most options are short dated, and foreign and domestic interest rate levels are not substantially different, symmetric pricing with respect to moneyness for puts and calls implies a coefficient equal to 1 when the intercept is zero. Because all the sample data were used in each regression, the estimated value cannot be attributed to the convex impact of moneyness on option pricing arising from a bias in the selection of specific put-call pairs for the sample. All the sample data is used for each regression. Recalling that the results in Tables 8 and 9 indicated overpricing of OTM calls and ITM puts, the regression results extend these observations to the full sample where the number of deviations for the conversion strategy outnumber the reversal deviations (e.g. 67,205 to 46, 987 for the Euro). This provides a larger (smaller) number of observations where it is most likely that OTM calls (ITM puts) will be over-priced.

\section{Conclusions}

This paper empirically examined two distribution free properties for currency options traded on Philadelphia Stock Exchange (PHLX) from 1 August 2005 to 31 July 2006. The two fundamental no-arbitrage conditions are a lower boundary condition (LBC) and put-call parity (PCP). Deviations from arbitrage conditions were investigated using alternative measures of transaction costs. 
Three measures of transaction costs were considered: (i) minimum transaction costs that involve only initial bid-ask spreads, (ii) transaction costs associated with trades closed out prior to expiration; and (iii) a total transaction costs measure. Even using minimum transaction costs calculated with closing spot $\mathrm{FX}$ and interest rate quotes, less than $1 \%(3 \%)$ of call (put) option prices involve deviations from the LBC. The LBC deviations are measured in fractions of a percent as alternative, more expensive, measures of transaction costs are employed. In contrast, PCP deviations for the conversion and reversal trades are $33.86 \%$ and $23.43 \%$, respectively, for all currencies jointly. Using round trip transactions costs, the PCP deviations are reduced on average, to $13.32 \%$ and $12.60 \%$ percent, respectively; reducing to 4.99 and 3.09 percent of all put-call pairs when total transaction costs are taken into account.

Author information: The submitting author is Professor Geoffrey Poitras of Simon Fraser University, Canada. He may be contacted at poitras@sfu.ca. The co-authors of the paper are respectively teaching staff Ariful Haque of University of Southern Queensland and Assoc Professor Meher Manzur of Curtin University, meher.manzur@cbs.curtin.edu.au.

\section{References}

Berg, E., Brevik, T., and Saettem, F. (1996). An examination of the Oslo stock exchange options market. Applied Financial Economics, 6, 103-113.

Bodurtha, J., and Courtadon, G. (1986). Efficiency tests of the foreign currency options market. Journal of Finance, 41, 151-162.

Bodurtha, J., and Courtadon, G. (1995). Probabilities and values of early exercise: spot and futures foreign currency options. Journal of Derivatives, 3, 57-75.

Demsetz, H. (1968). The cost of transacting. Quarterly Journal of Economics, 82, 33-53.

El-Mekkaoui, M., and Flood, M. (1998). Put-call parity revisited: intra daily tests in the foreign currency options market. Journal of International Financial Markets, Institutions and Money, 8, 357-376.

Garay, U., M. Ordonez and Gonzalez, M. (2003). Tests of the put-call parity relation using options on futures on the S\&P 500 Index. Derivatives Use, Trading \& Regulation, 9, 259-280.

Gould, J., and Galai, D. (1974). Transactions costs and the relationship between put and call prices. Journal of Financial Economics, 1, 105-129.

Hoque, A., Chan, F. and Manzur, M. (2008). Efficiency of the foreign currency options markets. Global Finance Journal, 19, 157-170.

Phillips, S., and Smith, C. (1980). Trading costs for listed options. Journal of Financial Economics, 8, 179-201.

Poitras, G. (2002). Risk management, speculation and derivative securities. New York: Academic Press. 
Poitras, G., Veld, C. and Zabolotnyuk, Y. (2009). European put-call parity and the early exercise premium for American currency options. Multinational Finance Journal, 13, 39-54.

Scotti, M., (2005 September 20). "PHLX gains new life". Traders.

Shastri, K., and Tandon, K. (1985). Arbitrage tests of the efficiency of the foreign currency options market. Journal of International Money and Finance, 4, 455-468.

Stoll, H. (1989). Inferring the components of the bid-ask spread: theory and empirical tests. Journal of Finance, 44, 115-134.

Vipul, (2008). Cross-market efficiency in the Indian derivatives market: A test of put-call parity. Journal of Futures Markets, 28, 889-910.

Wagner, D., Ellis, D., and Dubofsky, D. (1996). The factors behind put-call parity violations of S\&P 100 index options. Financial Review, 31 535552. 